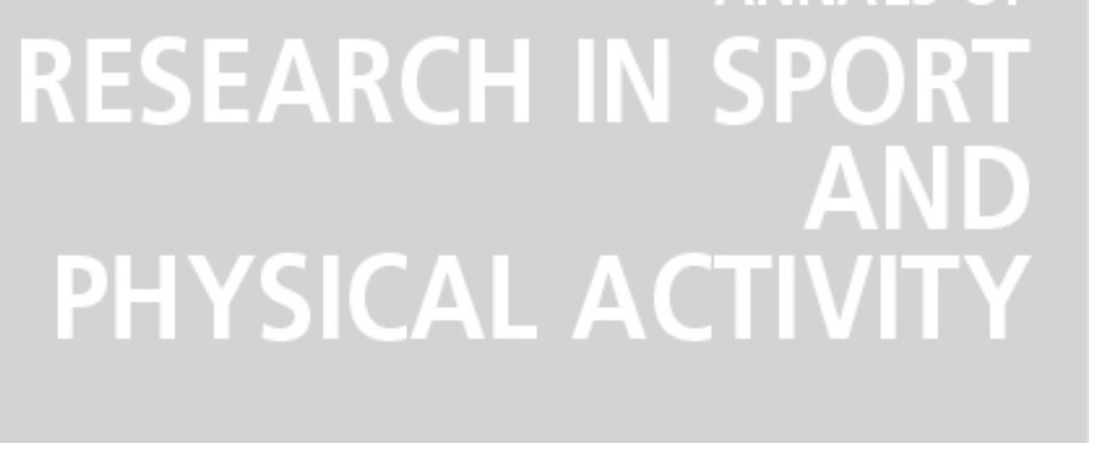

\title{
Training influences the acute immune response to a maximal swimming test
}

Autor(es): $\quad$ Monteiro, Cristina Paula; Morgado, José Pedro; Matias, Catarina Nunes; Reis, Joana Filipa; Laires, Maria José; Alves, Francisco

Publicado por: Imprensa da Universidade de Coimbra

URL persistente:

URI:http://hdl.handle.net/10316.2/44137

DOI: DOI:https://doi.org/10.14195/2182-7087_ex2018_74

Accessed : $\quad$ 26-Apr-2023 11:05:45

A navegação consulta e descarregamento dos títulos inseridos nas Bibliotecas Digitais UC Digitalis, UC Pombalina e UC Impactum, pressupõem a aceitação plena e sem reservas dos Termos e Condições de Uso destas Bibliotecas Digitais, disponíveis em https://digitalis.uc.pt/pt-pt/termos.

Conforme exposto nos referidos Termos e Condições de Uso, o descarregamento de títulos de acesso restrito requer uma licença válida de autorização devendo o utilizador aceder ao(s) documento(s) a partir de um endereço de IP da instituição detentora da supramencionada licença.

Ao utilizador é apenas permitido o descarregamento para uso pessoal, pelo que o emprego do(s) título(s) descarregado(s) para outro fim, designadamente comercial, carece de autorização do respetivo autor ou editor da obra.

Na medida em que todas as obras da UC Digitalis se encontram protegidas pelo Código do Direito de Autor e Direitos Conexos e demais legislação aplicável, toda a cópia, parcial ou total, deste documento, nos casos em que é legalmente admitida, deverá conter ou fazer-se acompanhar por este aviso. 


\section{ANNALS OF RESEARCH IN SPORT AND PHYSICAL ACTIVITY}




\section{TRAINING INFLUENCES THE ACUTE IMMUNE RE- SPONSE TO A MAXIMAL SWIMMING TEST}

Cristina Paula Monteiro'; José Pedro Morgado'; Catarina Nunes Matias; Joana Filipa Reis $^{2}$; Maria José Laires³; Francisco Alves ${ }^{1}$

Long-term endurance sports training influence on the acute immune response to exercise has been poorly studied, despite the complexity of both chronic and acute adaptations induced by training programs performed throughout the athlete's career. We aimed to evaluate the effects of training on the systemic and mucosal immune acute response to a maximal swimmingtest at 3 moments of a 4-month training cycle, in swimmers. Thirteen competitive swimmers (7 females, 6 males, 13 - 20 yrs) performed an incremental maximal step test (7×200 m front crawl) in 3 moments of the season: M1 - after a recovery microcycle, M2 - after a 5 week period of aerobic overload (volume increased by 20\%) and M3 - after 8 weeks of progressive decrease of volume and maintenance of intensity. Fasted blood and saliva samples were collected immediately before (6:30 a.m.) and 5 min after the swimming test, by standard procedures, for the assessment of leukogram (automated counter), lymphocytes subsets including CD3 ${ }^{+}, \mathrm{CD}^{+}, \mathrm{CD}^{+}, \mathrm{CD} 16^{+}$and CD19+ (Flow cytometry), serum immunoglobulin A (serum IgA; Nephelometry) and saliva IgA (slgA; ELISA). slgA secretory rate (srlgA) was calculated from slgA values. ANOVA for repeated measures, Friedman, and Wilcoxon tests were used for the assessment of training and sex effects. Statistical significance was set at $p<0.05$. The magnitude of the increase of leukocytes, total lymphocytes and subsets $\mathrm{CD}^{+}$and $\mathrm{CD}^{+}{ }^{+}$in response to the exercise test was greater at M3 compared to M1 in the whole group, and mean values for males were higher than for females. The magnitude of the leukocytosis and lymphocytosis was also greater at M3 compared to $\mathrm{M} 2$. Inversely, the magnitude of the decrease of the $\mathrm{CD}^{+} / \mathrm{CD}^{+}$ratio was smaller at M3. Regarding $\mathrm{CD}_{16}{ }^{+}$, the magnitude of its increase was greater at M3 com-

\footnotetext{
1 1Faculty of Human Kinetics, Laboratory of Physiology and Biochemistry of Exercise, University of Lisbon, Estrada da Costa, 1499-002, Cruz Quebrada, Dafundo, Portugal / Interdisciplinary Center of Human Performance Studies.

2 Universidade Europeia, Laureate International Universities, Lisboa, Portugal/Faculty of Human Kinetics, Laboratory of Physiology and Biochemistry of Exercise, University of Lisbon/Interdisciplinary Center of Human Performance Studies.

${ }^{3}$ Centro de Saúde Ambiental, Faculdade de Medicina de Lisboa, Lisbon, Portugal

Email: cmonteiro@fmh.ulisboa.pt
} 
pared to $M 1$, but only in females. No significant differences were observed between the responses of $\mathrm{CD}^{+}, \mathrm{CD}^{2} 9^{+}, \lg \mathrm{A}$, slgA and srlgA to the exercise tests. Swimmers increased the performance achieved in the maximal test from M1 to M2 and M3.During this training cycle, it was observed a stimulation of the systemic immune responsiveness and the maintenance of mucosal immune responsiveness to a maximal swimming exercise. Male swimmers had higher responsiveness of leukocytes, total lymphocytes and of the acquired immunity, represented by $C D 4^{+}$subsets, and contrarily, females had higher responsiveness of innate immunity, represented by $\mathrm{CD} 16^{+}$subsets, at M3. Although it is difficult to state if these changes reflect positive or negative adaptive mechanisms, training seems to be a main determinant of immune changes in the acute response to maximal exercise. 